\title{
Evaluation of Performance and Perception of Learning in Teaching Human Anatomy: Traditional Method vs Constructivist Method
}

\author{
Evaluación del Rendimiento y la Percepción del Aprendizaje en la Enseñanza \\ de la Anatomía Humana: Método Tradicional versus Método Constructivista
}

Roger W. S. Vitorino ${ }^{1}$; Célia Cristina Fornaziero ${ }^{1} \&$ Eduardo Vignoto Fernandes ${ }^{1,2}$

VITORINO, R. W. S. ; FORNAZIERO, C. C. \& FERNANDES, E. V. Evaluation of performance and perception of learning in teaching human anatomy: traditional method vs constructivist method. Int. J. Morphol., 38(1):74-77, 2020.

SUMMARY: The aim of the present study was to analyze the performance and perception of learning in relation to the Traditional Method (TM) and Constructivist Method (CM) in the teaching of Human Anatomy. The sample consisted of 76 students of the Physical Education course of the State University of Londrina, randomly distributed into two groups: TM and CM. The TM group received theoretical-expository and practical classes. The CM group was taken to the laboratory for practical classes and the participants of this class were allocated in up to seven per work table. Didactic materials and cadaveric parts were made available for consultation. After both intervention methods, the groups performed an evaluation on the studied content. The following week, a crossover was performed between the groups and, after the intervention, all participants were again evaluated. Before being given the outcome of their evaluations, participants were asked to answer questions about their perception of learning in relation to the above-mentioned methods. After the analysis, it was verified that the TM group obtained better results in the tests when compared to the CM group. In addition, according to students' perceptions, TM also favored learning more than CM. Therefore, it was evidenced in the present study that the traditional method was more favorable both for the quantitative performance and learning perception of the participants.

KEY WORDS: Active learning; Passive learning; Lecture; Teaching practices.

\section{INTRODUCTION}

Human Anatomy is considered one of the oldest medical sciences. Although it is a classical science, it continues to present great relevance in the training of university students in health areas, as professionals will use this knowledge in their practical activities (Ruzycki et al., 2019). In this context, research has been carried out with the aim of verifying the best teaching-learning strategy in Human Anatomy (Estai \& Bunt, 2016; Clunie et al., 2018; Sotgiu et al., 2019; Zilverschoon et al., 2019).

There is a discussion about the relationship between passive methodologies: where the teacher is the active subject in the teaching-learning process, for example, the traditional method (TM), also known as didactic lecture; and active methodologies, where the student is the active subject in the teaching-learning process and the teacher acts as a facilitating agent, guiding the students to seek and generate their own knowledge, for example, the constructivist method (CM) (Anderton et al., 2016; Lee \& Hannafin, 2016).

Currently, active methodologies are widely used in the teaching of Human Anatomy (Estai \& Bunt). Nevertheless, it has been verified that for the Anatomy and Human Physiology disciplines, teaching through TM continues to present better results and greater preference by students (Gogalniceanu et al., 2010; Davis et al., 2014). This information is linked to the fact that academics generally obtain better quantitative results (Anderton et al.).

However, there is still little research comparing active and passive methodologies using randomized research in conjunction with crossover between participants (Clunie et al.). Therefore, the aim of the present study was to analyze the performance and perception of learning in

\footnotetext{
${ }^{1}$ Department of Anatomy, Universidade Estadual de Londrina, Londrina, Paraná, Brazil.
}

${ }^{2}$ Universidade Federal de Goiás - Regional Jataí, Jataí, Goiás, Brazil. 
VITORINO, R. W. S. ; FORNAZIERO, C. C. \& FERNANDES, E. V. Evaluation of performance and perception of learning in teaching human anatomy: traditional method vs constructivist method. Int. J. Morphol., 38(1):74-77, 2020

relation to the Traditional Method and Constructivist Method in the teaching of Human Anatomy.

\section{MATERIAL AND METHOD}

Participants: The sample consisted of 76 students of the Physical Education course of the State University of Londrina, Paraná, Brazil. Recruitment occurred voluntarily during Human Anatomy classes and the volunteers signed the free and informed consent term. The work was approved by the Ethics Committee on Human Beings of UEL (proc. CAAE: 79469417.4.0000.5231), a crosssectional study.

Procedures: Participants were randomly assigned to two groups: Traditional Method (TM) and Constructivism Method (CM). The TM group attended a theoretical lecture for 50 minutes (with PowerPoint) and a practical class for 50 minutes (in the Human Anatomy laboratory with previously dissected cadaveric parts).

In relation to the $\mathrm{CM}$ group, the participants were taken to the Human Anatomy laboratory and distributed in groups of up to seven students per worktable for 100 minutes, the same TM structures. They received an instruction script prepared by the teachers, as well as a textbook, atlas of Anatomy, and previously dissected cadaveric parts. The students were required to identify, in the corpse, the structures described in the script and whenever they had doubts, they could request assistance from the teacher.

In the second part of the study, the crossover occurred so that all students participated in both methods. In both times, the content addressed was the muscular system (upper limb in first week and lower limb second week of study). In the first and second (cross over) intervention, independently of the group, immediately after the methods were performed, the participants carried out an evaluation on the content worked on. After completing this evaluation, the students answered two questions about their perception of learning (without prior knowledge of the results of their evaluations), adapted according to Mota et al. (2010). Question 1: How would you rate your learning?; Question 2: Did the method used contribute to improving your learning.

Initially, the quantitative data were submitted to the Shapiro-Wilk normality test. After verifying that the data did not present normality, the comparison between the TM and CM groups was performed using the Mann-Whitney test. For evaluation of categorical variables, Fisher's exact test was used. The association between the students' perception of learning in the methodologies was evaluated by the Odds Ratio (OR) with a Confidence Interval (CI) of $95 \%$. Statistical analyzes were performed using the GraphPad Prism 6.0 statistical package, with a minimum significance index of $\mathrm{p}<0.05$.

\section{RESULTS}

Figure 1 presents the performance of the students in relation to TM and CM. It can be observed that TM resulted in better student performance when compared to $\mathrm{CM}$, $\mathrm{p}<0.0001$.

Regarding the perception of learning, it was verified that TM was more favorable than CM (effect size, $31.5 \%$ ), that is, 62 students classified their learning as excellent/good when they performed TM, while only 38 students reported their learning as excellent/good when they performed CM. Statistical significance association between "How would you rate your learning?" and TM was observed (Table I).

When asked whether TM or CM contributed to improving learning, most participants answered yes for TM (effect size, $26.3 \%$ ), that is, 72 of the individuals in the TM group, while only 52 answered yes for CM. Statistical significance association between "Did the method used contribute to improving your learning?" and TM was observed (Table I).

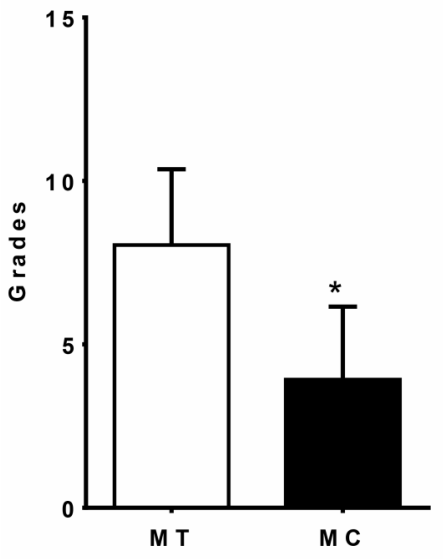

Fig. 1. Comparison between the traditional method and the constructivist method in relation to student performance. The Mann-Whitney test was used to compare the groups, $\mathrm{p}<0.05$. TM, traditional method $(\mathrm{n}=76) ; \mathrm{CM}$, constructivism method $(\mathrm{n}=76) .{ }^{*}, \mathrm{CM}$ different from TM. 
Table I. Association between teaching methods and students' perception of learning.

\begin{tabular}{lcccc}
\hline Questions & TM $(\mathrm{n}=76)$ & $\mathrm{CM}(\mathrm{n}=76)$ & $\mathrm{OR}(95 \% \mathrm{CI})$ & $\mathrm{p}^{*}$ \\
\hline How would you rate your learning? & 62 & 38 & $4.42(2.12-9.22)$ & 0.0001 \\
$\begin{array}{l}\text { Excellent/Good } \\
\text { Regular/Bad }\end{array}$ & 14 & 38 & & \\
$\begin{array}{l}\text { Did the method used contribute to } \\
\text { improving your learning? }\end{array}$ & 72 & 52 & & \\
Yes & 4 & 24 & & \\
No & & & & \\
TM: traditional method; CM: constructivist method; OR: odds ratio; CI: confidence interval; *Fisher's exact test.
\end{tabular}

\section{DISCUSSION}

The present study evaluated the performance and learning perception of students of the Physical Education course through TM and CM in the discipline of Human Anatomy. Regarding TM, it was verified that the students presented better performance in the quantitative evaluations and, according to their perceptions, also experienced greater learning.

This can be explained by the fact that educational institutions, in general, use the traditional method in their curricula, from primary to higher education (Lee \& Hannafin). As a result, university students find it difficult to assimilate new teaching proposals. Thus, it is recommended that students newly enrolled in higher education (habituated to passive methodologies) be introduced to active methodologies before they are effectively applied (Davis et $a l$.). This did not happen in the present study, in which participants were submitted to CM without previous familiarization.

With respect to the perception of learning, the fact that the students prefer TM, instead of CM, may be related to the difficulty students have in distinguishing the key concepts from the studied content. In TM, the responsibility to process the pertinent contents of the discipline comes from the teacher; the students do not need to develop autonomy of study, a fact that generates insecurity in the student (Lee \& Hannafin).

Davis et al. report that students point out that new teaching strategies should always be tested and developed, however, TM should not stop being the basis of the curriculum, as, in addition to resulting in better use of disciplines, students admit to feeling more secure when learning the content taught by the teacher.

Therefore, research in the field of teaching pedagogy does not classify a method as the best or the worst, but rather, as the most appropriate for a given content, discipline, or class (Estai \& Bunt). Thus, the teacher should be able to combine the use of passive and active methodologies, a circumstance that could broaden the teaching-learning process (Maphosa \& Ndebele, 2014).

Although there is a demand for innovations in teaching methodologies, Anderton et al. demonstrate that TM is still maintained in the curricula of the courses of health sciences, mainly for the discipline of Human Anatomy. This situation can be justified by the fact that people are accustomed to TM and initiating new teaching proposals that would not necessarily be more effective creates difficulty for both teachers and students.

Nowadays, technological advances have generated many subsidies for teaching. In this sense, there is growing consensus that combinations between technological and pedagogical resources can provide benefits to the performance and, consequently, the learning of the students in the teaching of Human Anatomy (Lochner et al., 2016; Trelease, 2016; Oliveira et al., 2019; Sotgiu et al.). This condition is reported by students, who demonstrate that they benefit more from the traditional method when it is accompanied by complementary pedagogical resources, e.g., synthetic models, virtual reality (3D visualization), and multimodal approaches (Papa \& Vaccarezza, 2013; Estai \& Bunt; Ruzycki et al.). Thus, integration of the traditional method with technological resources could be an alternative to enhance the teaching of Human Anatomy.

Although the traditional method presented a perspective of better acceptance by the investigated sample. In view of the above, we conclude that that the traditional method was more favorable both for the quantitative performance and learning perception of the participants.

\section{ACKNOWLEDGMENTS}

This work was supported by Fundação Araucaria (Scientific Initiation Program fellowship to RWSV, order number: 11182). 
VITORINO, R. W.S. ; FORNAZIERO, C. C.\& FERNANDES, E. V. Evaluación del rendimiento y la percepción del aprendizaje en la enseñanza de la anatomía humana: método tradicional versus método constructivista. Int. J. Morphol., 38(1):74-77, 2020.

RESUMEN: El objetivo del presente estudio fue analizar el rendimiento y la percepción del aprendizaje en relación con el Método Tradicional (MT) y el Método Constructivista (MC) en la enseñanza de la Anatomía Humana. La muestra consistió en 76 estudiantes del curso de Educación Física de la Universidad Estatal de Londrina, distribuidos aleatoriamente en dos grupos: MT y MC. El grupo MT recibió clases teórico-expositivas y prácticas. El grupo MC fue llevado al laboratorio para clases prácticas y los participantes de esta clase fueron asignados en hasta siete por mesa de trabajo. Los materiales didácticos y las piezas cadavéricas se pusieron a disposición para consulta. Después de ambos métodos de intervención, los grupos realizaron una evaluación del contenido estudiado. La semana siguiente, se realizó un cruce entre los grupos y, después de la intervención, todos los participantes fueron evaluados nuevamente. Antes de recibir el resultado de sus evaluaciones, se les pidió a los participantes que respondieran preguntas sobre su percepción del aprendizaje en relación con los métodos mencionados anteriormente. Después del análisis, se verificó que el grupo MT obtuvo mejores resultados en las pruebas en comparación con el grupo MC. Además, según las percepciones de los estudiantes, MT también favoreció el aprendizaje más que MC. Por lo tanto, se evidenció en el presente estudio que el método tradicional era más favorable tanto para el rendimiento cuantitativo como para la percepción del aprendizaje de los participantes.

PALABRAS CLAVE: Aprendizaje activo; Aprendizaje pasivo; Conferencia; Prácticas docentes.

\section{REFERENCES}

Anderton, R. S.; Chiu, L. S. \& Aulfrey, S. Student perceptions to teaching undergraduate anatomy in health sciences. Int. J. High. Educ., 5(3):20116, 2016.

Clunie, L.; Morris, N.; Joynes, V. C. T. \& Pickering, J. D. How comprehensive are research studies investigating the efficacy of technology-enhanced learning resources in anatomy education? A systematic review. Anat. Sci. Educ., 11(3):303-19, 2018.

Davis, C. R.; Bates, A. S.; Ellis, H. \& Roberts, A. M. Human anatomy: let the students tell us how to teach. Anat. Sci. Educ., 7(4):262-72, 2014.

Estai, M. \& Bunt, S. Best teaching practices in anatomy education: A critical review. Ann. Anat., 208:151-7, 2016.

Gogalniceanu, P.; Palman, J.; Madani, H.; Sheena, Y.; Birch, W.; Paraskeva, P. \& Douek, M. Traditional undergraduate anatomy education--a contemporary taboo? A. N. Z. J. Surg., 80(1-2):6-7, 2010.

Lee, E. \& Hannafin, M. J. A design framework for enhancing engagement in student-centered learning: own it, learn it, and share it. Educ. Technol. Res. Dev., 64(4):707-34, 2016.

Lochner, L.; Wieser, H.; Waldboth, S. \& Mischo-Kelling, M. Combining traditional anatomy lectures with e-learning activities: how do students perceive their learning experience?. Int. J. Med. Educ., 7:69-74, 2016.

Maphosa, C. \& Ndebele, C. Interrogating the skill of introducing a lecture: towards an interactive lecture method of instruction. Anthropologist, 17(2):543-50, 2014.
Mota, M. F.; da Mata, F. R. \& Aversi-Ferreira, T. A. Constructivist pedagogic method used in the teaching of human anatomy. Int. J. Morphol., 28(2):369-74, 2010.

Oliveira, M.; Geambastiani, P.; Lopez, G.; Cambui, M.; Ubeda, C. \& Mdletshe, S. The development of a free radiological anatomy software teaching tool. Int. J. Morphol., 37(1):205-11, 2019.

Papa, V. \& Vaccarezza, M. Teaching anatomy in the XXI century: new aspects and pitfalls. Sci. World J., 2013:310348, 2013.

Ruzycki, S.; Desy, J. R.; Lachman, N. \& Wolanskyj-Spinner, A. P. Medical education for millennials: How anatomists are doing it right. Clin. Anat., 32(1):20-5, 2019

Sotgiu, M. A.; Mazzarello, V.; Bandiera, P.; Madeddu, R.; Montella, A. \& Moxham, B. Neuroanatomy, the Achille's heel of medical students. A systematic analysis of educational strategies for the teaching of neuroanatomy. Anat. Sci. Educ., 2019. doi: 10.1002/ase.1866. In press.

Trelease, R. B. From chalkboard, slides, and paper to e-learning: How computing technologies have transformed anatomical sciences education. Anat. Sci. Educ., 9(6):583-602, 2016.

Zilverschoon, M.; Kotte, E. M. G.; van Esch, B.; Ten Cate, O.; Custers, E. J. \& Bleys, R. L. A. W. Comparing the critical features of e-applications for three-dimensional anatomy education. Ann. Anat., 222:28-39, 2019.

Corresponding author:

Dr. Eduardo Vignoto Fernandes

Laboratório de de Anatomia Humana e Comparativa

Universidade Federal de Goiás - Regional Jataí

Rodovia BR 364, km 195, nº 3800

Campus Jatobá

CEP 75801-615

Jataí

Goiás

BRAZIL

Email: eduardovignoto@uel.br eduardovignotofernandes@gmail.com

Received: 30-05-2019

Accepted: 24-07-2019 